\title{
An Early Look at the Volatility of Money and Interest Rates under CRR
}

\author{
Daniel L. Thornton
}

N February 2, 1984, the Federal Reserve enacted a system of contemporaneous reserve requirements (CRR) to replace the system of lagged reserve requirements (LRR) that had been in effect since September 1968. The Fed made this change in response to widespread criticism that, under a reserve target operating procedure, LRR made it more difficult to control the monetary aggregates and contributed to the volatility of money and, perhaps, interest rates. Thus, critics believed a return to CRR would reduce the volatility of money and might reduce the volatility of interest rates as well."

The purpose of this atticle is to determine whether the return to CRR has had, so far, any significant impact on the variability of money and interest rates. The article begins with a concise review of the arguments bearing on the presumed effects of the change from

Daniel $L$. Thornton is a senior economist at the Federal Reserve Bank of St. Louis. John $G$. Schutte provided research assistance.

See Thornton (1983b) and the references cited there.
LRR to CRR on the volatility of money or interest rates. The actual behavior of these variables is then examined to see whether arguments in favor of the retum to CRR have been supported.

\section{WHAT CRR IS SUPPOSED TO ACCOMPLISH: THE STANDARD ANALYSIS}

The rationale for returning to CRR rests primarily on the argument that LRR weakens the contemporaneous link between reserves and deposits of depository institutions. For example, it was argued that depository institutions would have no incentive to curtail their lending activities under LRh because they are not required to hold reserves against the deposits that these activities create until the following week. Consequently, an increase in loan demand would be more readily transmitted into a change in the money stock in the short run under LRR.

At a more formal level, the case for CRR was usually presented in terms of the supply of and demand for 


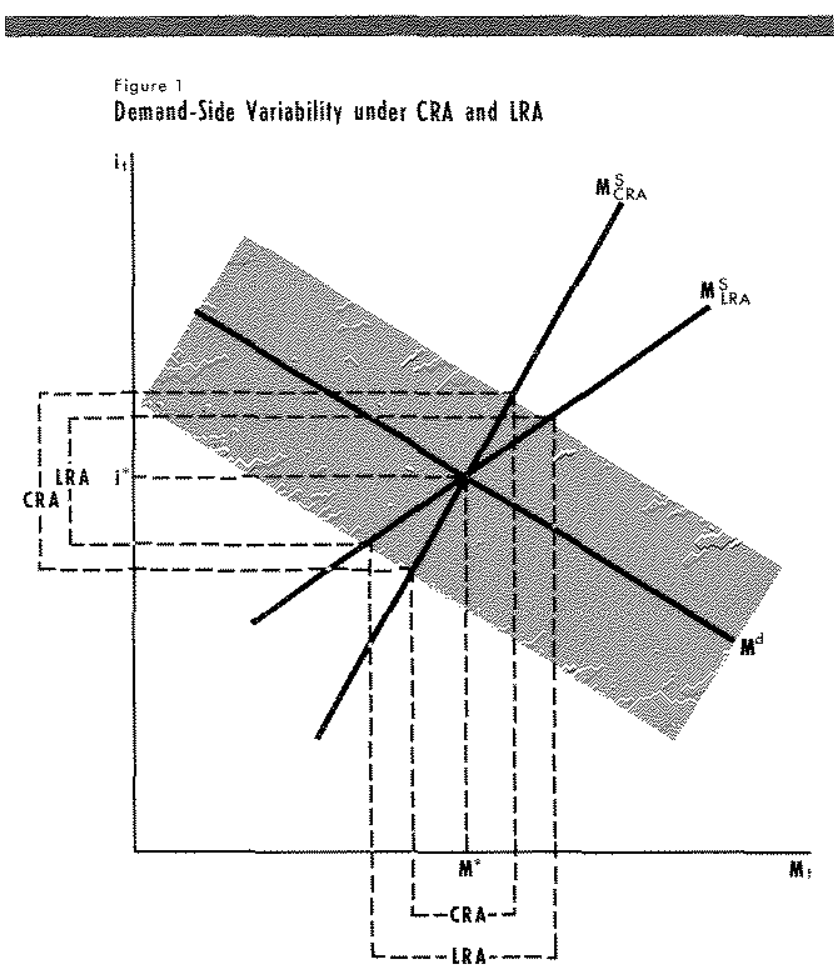
argued that the money supply schedule is flatter under LRR than under CRR. This is illustrated in figures 1 and 2. Consequently, random variation in the demand for money (represented by the shaded area in figure 1 ) results in more variability in the stock of money and less variability in the interest rate under LRR, as illustrated in figure 1 . Also, random variation in the supply of money (represented by the shaded areas in figure 2 ) results in more variability in money and interest rates under LRR. Thus, compared with CRR, LRR produces greater variation in the money stock. Whether interest rates are also more variable depends on the relative magnitude of the variance of the supply-side and demand-side disturbances. ${ }^{2}$

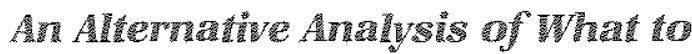

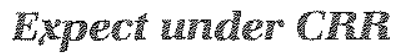

There are two reasons why the result predicted above need not occur. First, depository institutions' behavior may not be as sensitive to the reserve ac counting system in effect as this analysis suggests. Consequently, the switch from LRR to CRR may not significantly alter the week-to-week variability of

There are other factors, not considered here, that also affect the outcome; see thornton (1983b) and the references cited there.

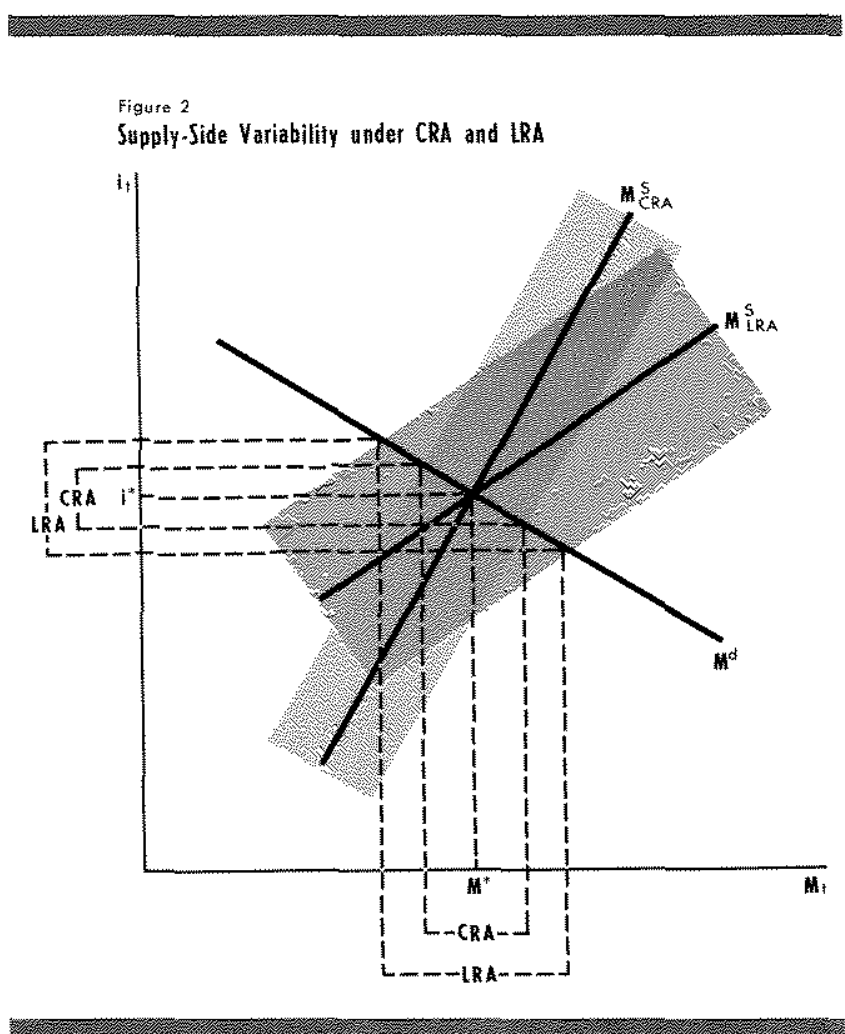

money and interest rates, at least in the short run. Second, the suggested outcome is predicated on the assumption that the Federal Reserve is targeting on a reserve aggregate. If the Federal Reserve is not targeting explicity on money of a reserve aggregate in the short run, the variability of money and interest rates will not necessarily be related to the reserve accounting svstem.

The first view argues that the short-run contemporaneous link between depository institutions' decisions to make additional loans and investments and their holdings of reserves need not be close even under a system of CRR. ${ }^{3}$ In the short run, depository institutions can obtain additional reserves by borrowing from the Federal Reserve or holding temporarily fewer excess reserves than they would hold otherwise. These factors may be sufficient to accommodate most short-run, week-to-week supply- and demand-side disturbances. Consequently, the slopes of the money supply schedules under LRR or CRR may be similar. Unless the adoption of CRR fundamentally changes the way that depository institutions adjust their reserve positions, there may be no dramatic change in the volatility of money and interest rates in the short run.

3See Thomton (1983b) for a more detailed explanation of the arguments presented in this section. 
This conjecture is likely to be even more valid given that the new CRR system lengthened the reserve settlement period from one to two weeks. ${ }^{4}$ Depository institutions may now make loans early in the accounting period, waiting to settle through the discount window, the money market or changes in excess reserves) toward the end of the period. By accommodat ing loan demand at the first part of the period and settling later in the period, week-to-week variability in money and interest rates could be similar under the new system of CRR and the old system of LRR.

\section{The Role of Federal Feserye Operating Procedures}

Expectations of differential effects in the variability of money and interest rates under CRR and LRR are based on the assumption that the Federal Reserve is attempting to hit a monetary target by manipulating a reserve aggregate. If this is not the case, there is little reason to expect differential effects associated with a change in the reserve accounting system. For example, week-to-week variability of money and interest rates are unaffected by the choice of reserve accounting system under an interest rate targeting procedure. ${ }^{\circ}$

This point is important because the Federal Reserve changed operating procedures in the fall of 1982 , about a year and a half before the implementation of CRR. The Federal Open Market Committee (FOMC) followed a reserve aggregate targeting procedure that placed greater emphasis on movements in $\mathrm{M} 1$ as a policy guide from October 6, 1979, to early October 1982. 'Since then, the FOMC has placed less emphasis on the behavior of $\mathrm{M} 1$ in the short run, aiming instead at longer-run monetary and credit aggregate objectives. This policy has been implemented in the short

\footnotetext{
4For a discussion of the new system, see Gilbert and Trebing (1982). For an interesting analysis of the carryover provision of the new system of CRR, see Spindt and Tarhan (1984)

some have suggested that the Federal Reserve has no choice but to accommodate this credit expansion, since the additional reserves needed to support the new deposits can only come into the systern via the discount window. This argument comes perilously close to saying that the Federal Reserve must accommodate credit demand completely under LRR. This position, however, ignores the $d y-$ namics of these long-run adjustments. For another view of this process, see Thomton (1982), p. 29.

'The short-run money supply schedule is completely flat (interestelastic). Thus, the variability of money would be completely determined by the random variation in the demand for money, and this would be unaffected by the reserve accounting system.
}

'For a discussion of the issues surrounding the decision to deemphasize $M \dagger$ as an intermediate target, see Thonton (1983a). run through a "flexible nonborrowed wreserves path." "s As a result of this procedural change, the variability of money and interest rates immediately before and after the implementation of CRR may reveal little change.

\section{WAS TIIE VARTARIUITU OF MONEY AND WNTEPEST PATES CWANGED SWNER CRP?}

Before a comparison of the weekly variability of money and interest rates for periods before and after the adoption of CRR can be made, one must decide what measure of variability to use. The measure used here is the average absolute percentage change (AAPC)." This is preferable to two more commonly cited measures, the standard deviation and the coefficient of variation, as a measure of the short-run, week-to-week variability that this article is concerned with (see the insert on page 30 ).

Data are presented for various subperiods to reflect both the move from LRR to CRR and the change in Federal Reserve operating procedures. Data for the two weeks immediately before and after the implementation of CRR were excluded to guard against the possibility that they were contaminated by expectations or other problems associated with the implementation of the new procedure.

Results for the money stock, M1, are presented in table 1. The AAPC of seasonally adjusted M1 appears to have increased significantly in the 28 -week period following the implementation of $\mathrm{CRR}$, compared with that of the 28-week period immediately before CRR. The AAPC of seasonally adjusted M1 increased from about 0.13 percent to 0.43 percent, a difference that is significant at the 5 percent level. ${ }^{10}$ When the most recent period is compared with a similar period in 1983, the increase is much smaller; nevertheless, it is statistically significant."

These comparisons, however, are deceptive because revised seasonally adjusted data is "smoother" than preliminary seasonally adjusted data. Thus, the significant increase in the variability of seasonally ad-

\footnotetext{
Wallich (1984), p. 26. Also, see Solomon (1984).

9The AAPC is defined as AAPC $(X)=(1 /(T-1)) \sum_{t=1}^{T}$

$\left(\left|X_{1}-X_{t-1}\right| / X_{t-1}\right) 100$. It is a measure of relallve varlability in that AAPC $(k X)=A A P C(X)$, where $k$ is an arbitrary constant.

${ }^{10}$ The t-statistic is 5.20 .

"The t-statistic is 3.15 .
} 
Table

The Varlabilty of 11

\begin{tabular}{|c|c|c|c|}
\hline Perrod & $\begin{array}{l}\text { Segasonally } \\
\text { adjusied }\end{array}$ & $\begin{array}{l}\text { lot seasongly } \\
\text { adjusted }\end{array}$ & $\begin{array}{l}\text { firstipubilsted } \\
\text { seasonally a diusted }\end{array}$ \\
\hline $20789=90604$ & $0.45 \%$ & $161 \%$ & $0,44 \%$ \\
\hline 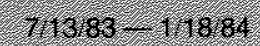 & 0.16 & 1.46 & 0.36 \\
\hline 30280 , 910708 & 128 & $5 \%$ & 0.44 \\
\hline
\end{tabular}

Table? 2

The Variability of M1 and Selected Interest Rates

\begin{tabular}{|c|c|c|c|c|c|}
\hline Perou & $\begin{array}{l}\text { nevised } \\
\text { torabonaly } \\
\text { adiusted }\end{array}$ & $\begin{array}{l}\text { Fist publinged } \\
\text { seasomany adujusted }\end{array}$ & treseral & Tranur) & $\begin{array}{c}\text { Crungral } \\
\text { paper }\end{array}$ \\
\hline 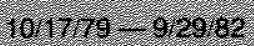 & $622 \%$ & $50 \%$ & $4.48 \%$ & $3,91 \%$ & $411 \%$ \\
\hline $10116.82=9.20183$ & 0.24 & 46 & 252 & 190 & 101 \\
\hline
\end{tabular}

For week eniong two days ta ter than dalo shown

justed M1 with the implementation of CRR may be a statistical artifact of the seasonal adjustment revision."

This is investigated by a comparison of the AAPC over the three periods using either not seasonally adjusted or first-published seasonally adjusted data. If the increased variability is primarily the result of the seasonal adjustment revision rather than the change in the reserve accounting system, then the AAPC for the first-published or not seasonally adjusted M1 should be essentially the same over these periods," Likewise, a comparison of not seasonally adjusted data for the 28 -week period since the implementation of CRR and the corresponding period a year earlier should reveal no change in the AAPC. The data are consistent with both of these conditions. Thus, there appears to be no change in the variability of $M 1$ between the pre- and post - CRR periods.

It is indeferminant, however, whether this result stems from depository institutions not changing their

12For example, see Hein and Ott (1983).

${ }^{3} \mathrm{~A}$ comparison of these data is perhaps more relevant because these are the figures that economic agents and policymakers use fo make their decisions. behavior following the enactment of CRR or from a change in the operating procedure in the fall of 1982 . In order to determine which explanation is more consistent with the facts, the AAPC was calculated for M1 and three interest rates - the federal funds rate, the three-month Treasury bill rate and the commercial paper rate - for the three-year period of reserve ag gregate targeting lOctober 17, 1979, to September 29, 1982) and for the year immediately following the change in the Federal Reserve's operating procedure (October 6, 1982, to September 28, 1983). These results are presented in table 2 . The data indicate a decline in the AAPC for both revised and first-published $\mathrm{M} 1$ after the fall of 1982; however, this decline is not statistically significant at the 5 percent level.14 Thus, it, appears there was no significant change in the week-to-week variability of M1 following the change in the operating procedures.

The AAPCs for all three interest rates, however, decrease significantly after the fall of 1982 . Thus, it appears that the change in operating procedure had some impact on the behavior of interest rates. Hence,

\footnotetext{
:The relevant t-statistics for first-published and not seasonally adjusted data are 0.91 and 0.15 , respectively.
} 


\section{The limitations of t wo Common Mensures of Vantability}

Moth ne standard dovation $9 \mathrm{SD}$ and the roef ficient of katiation ent measure the variability of thro data relativet o an average for the 80 ihe aver age is the nean of Hie raw data, tor hed Whe mean is unity that is, the duerage of the tat data diviled hy the near. Thus, ine sto s a measume of absolute varabilito and the CV is a neasire of relatre varta biliv:

Because hath or hese statistics iverage squared reviations from heir respertife neans. Hiev may

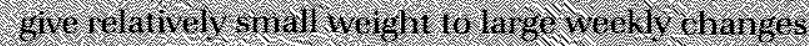
and relatwely large weight to snall Wreckly el wanges.

$$
\begin{aligned}
& \text { (3) }
\end{aligned}
$$

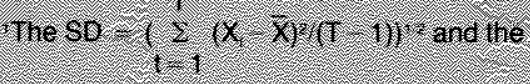

$$
\begin{aligned}
& \text {. } 1 . \\
& \text { Cr. } \\
& \text { wherexis heviean or herav series. }
\end{aligned}
$$

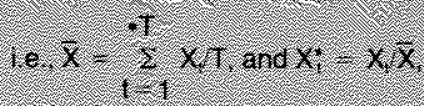

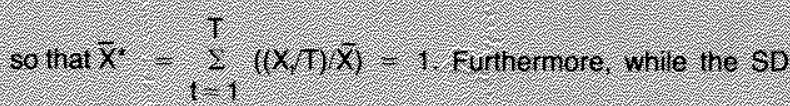

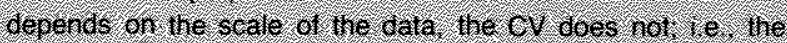
constinter lhis is intistrated in ine afcompanvime chath:

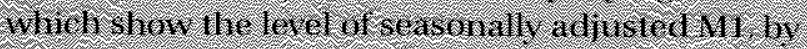
iself and rehative to its mean level for the 28 ireek

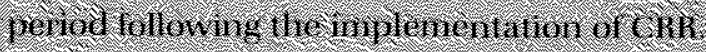

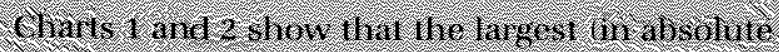
And relative termst one week change in Mr or

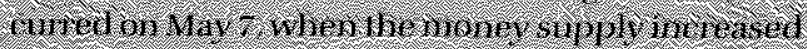
hy 5.3 biltion becanse the absolure and relative

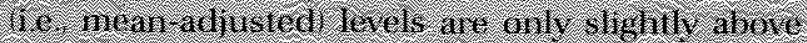
Nher is pective means tor the peribd their tespet:

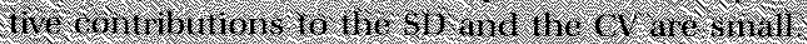

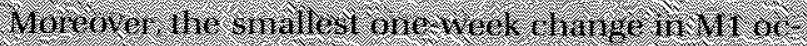

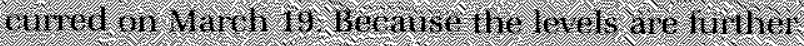

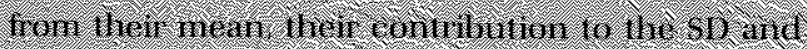
the c v is fanget than that or Ihe largest chinge.

The arotage absolute percentage chamie s A DC: is a measure of relative satrabilit lint weics the problem of inaporopiate veighting 1 hus it is a

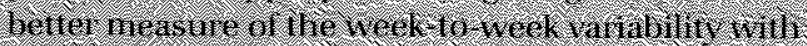
Which this andel is ron ermer:

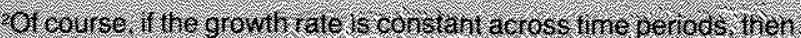

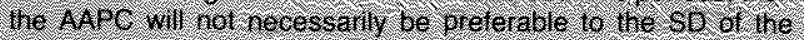

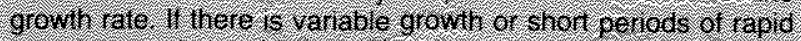

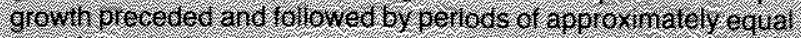

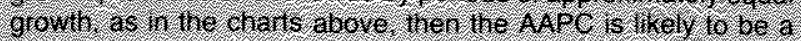

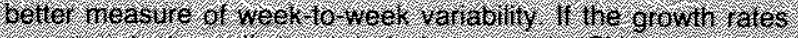

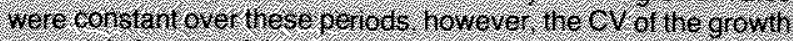

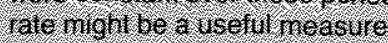

it is possible that the lack of a significant change in the variability of money after the implementation of CRR was due to the earlier change in operating procedures. Unfortunately, these results cannot rule out the possibility that the short-run reserve management behavior by depository institutions is simply insensitive to changes in the reserve accounting system..$^{15}$

\section{The Variability of Interes Rates}

The AAPC was calculated for the federal funds, the three-month Treasury bill and the 30-day commercial paper rate for comparable 28 -week periods before and after the implementation of CRR. The results, which are reported in table 3 , indicate a slight increase in the ${ }^{15}$ Neither of these, however, fules out other potential gains from CRR.
See Goodfriend (1984).
AAPC for the federal funds rate for periods immediately before and after the implementation of CRR and a slight decrease for both the Treasury bill rate and the commercial paper rate; however, none of these were

\begin{tabular}{|c|c|c|c|}
\hline Perod & $\begin{array}{l}\text { Peoreral } \\
\text { runcs. }\end{array}$ & $\begin{array}{l}\text { Treasury } \\
\text { bils }\end{array}$ & Commercia \\
\hline 22484.096164 & $256 \%$ & $1.18 \%$ & $1+136$ \\
\hline $7 \times 15,60+7120.84$ & 2.35 & $(x)$ & $(27$ \\
\hline 80486.90968 & 89 & 58 & 456 \\
\hline
\end{tabular}

Table 3

\section{The Variability of Selected interest Rates}


Chart 1

Levels of $M 1$

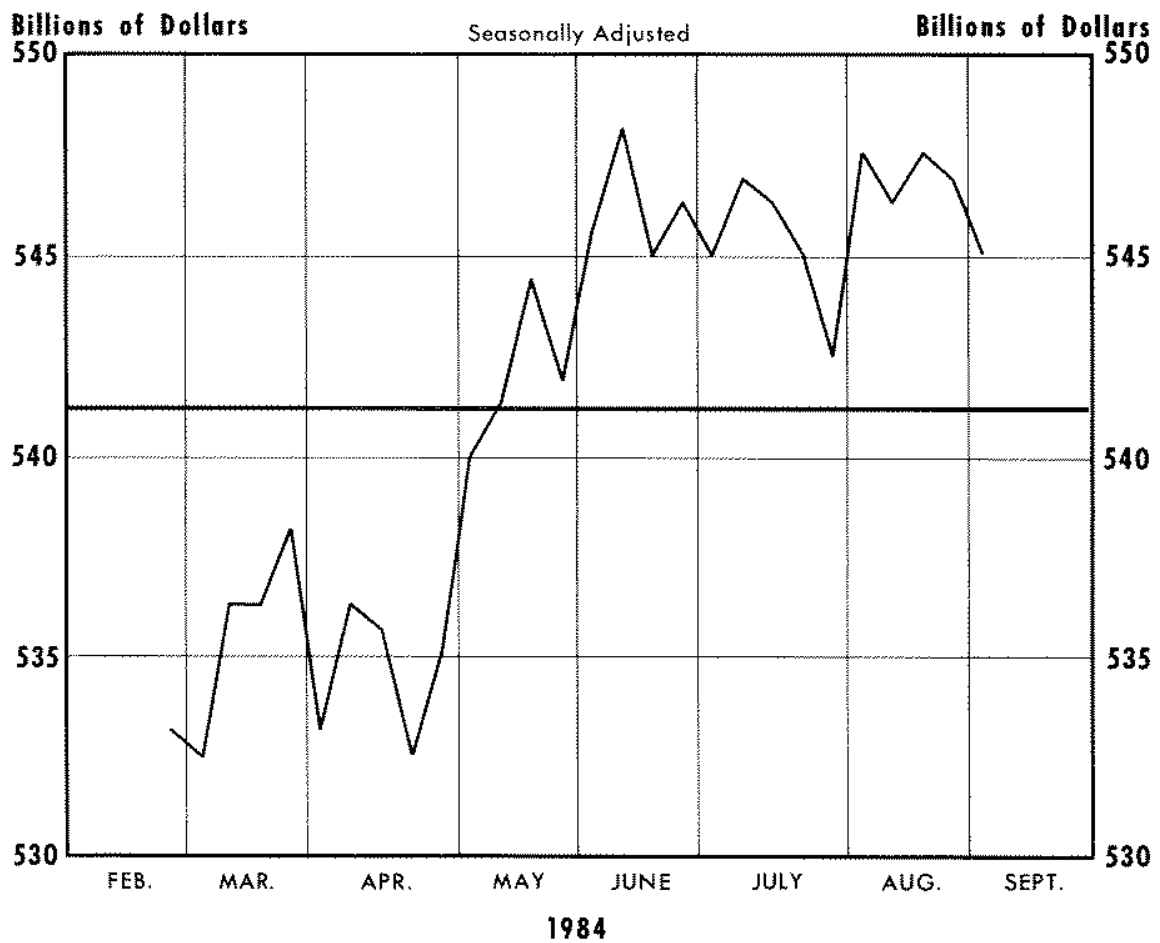

Chat 2

\section{Ratio of M1 to Sample Mean}

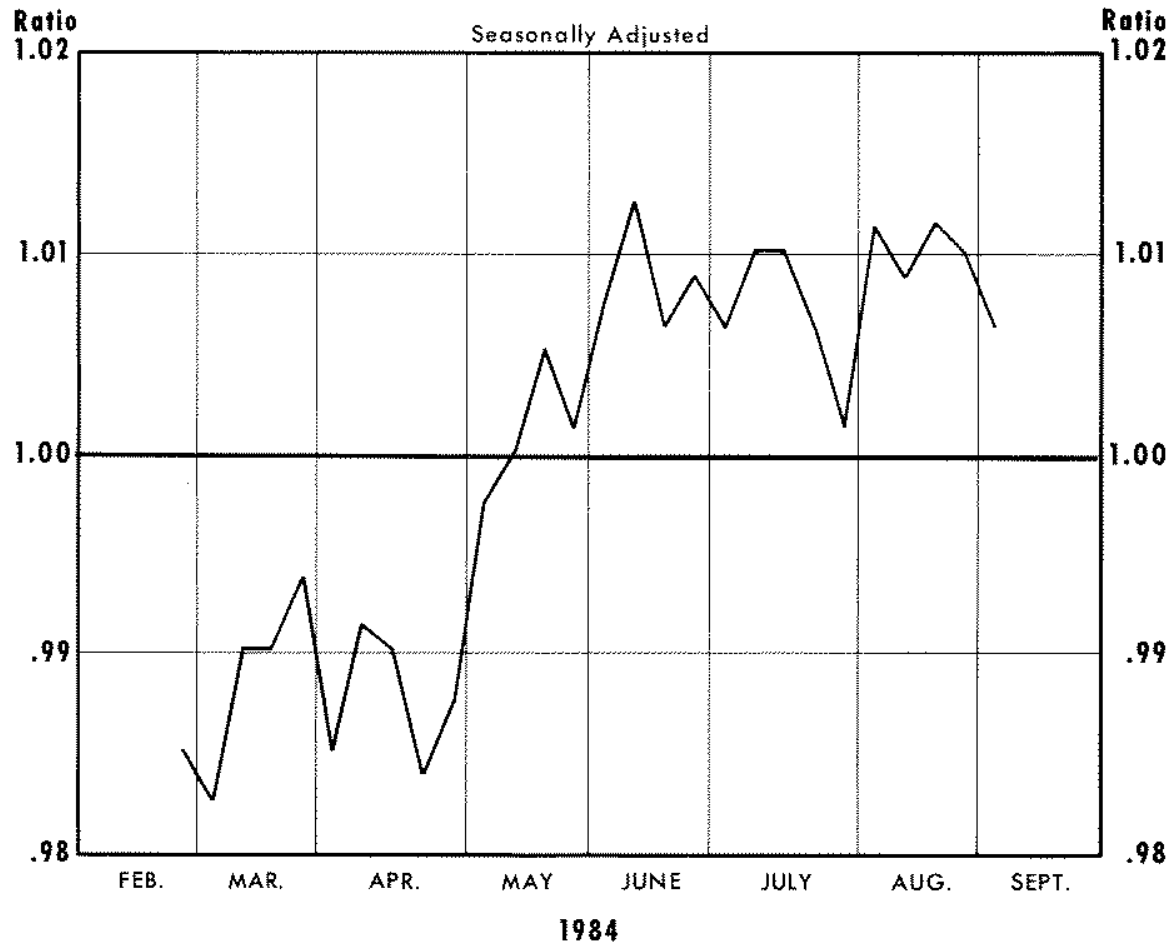


significant at the 5 percent level. ${ }^{16}$ Thus, the results suggest that the implementation of CRR had little ef fect on the variability of money or interest rates. The significant reduction in interest rate variability appears to correspond with the earlier change in operating procedures, not with the implementation of CRR.

\section{CONCLUSIONS}

The purpose of this afticle was to take an early look at the effect of the Federal Reserve's new system of contemporaneous reserve accounting on the variability of money and interest rates. Although the CPR system was adopted with the expectation that it would reduce the variability of money under a reserve targeting procedure, it may not have that effect for two reasons. First, depository institutions may behave in ways that reduce the short-run contemporaneous link between aggregate reserves and deposits even under CRR. Second, the change in operating procedures in October 1982 may have preempted any potential benefits from the switch in accounting systems.

The data fot M1 indicate that there was no significant change in week-to-week variability following either the change in operating procedure in October 1982 or the adoption of CRR. The variability of shortrun interest rates declined significantly after the change in operating procedures, but has been unaffected by the implementation of CRR. Thus, the change in the reserve accounting procedure had no

${ }^{15}$ The relevant twstatistics for a comparison of periods immediately before and after the implementation of CAR for the federal tunds rate, the threemonth Treasury bill rate and the commercial paper rate are $0.30,0.39$ and 0.53 , respectively. statistically significant impact on the variability of money either because depository institutions' lending and investment decisions are insensitive to the reserve accounting system, or because of the change in operating procedures that occurred some year and a half earlier. Consequently, CRR's potential usefulness in reducing the variability of money can be determined for certain only if the Federal Reserve implements a strict reserve aggregate or monetary base target.

\section{REFERENCES}

Gilber, R. Alton, and Michael E. Trebing. "The New System of Contemporaneous Reserve Requirements, "this Review (Decem" ber 1982), pp. $3-7$

Goodfriend, Marvin. "The Promises and Pitfalls of Contemporaneous Reserve Requirements for the Implementation of Monetary Policy," Federal Reserve Bank of Richmond Economic Review (May/June 1984), pp. 3-12

Hein, Scott $E$, and Mack Ott. "Seasonally Adjusting Money: Procedures, Problems, Proposals," this Review (November 1983), pp. 16-25.

Spindt, Paul A., and Vefa Tarhan. "Bank Reserve Adjustment Pro" cess and the Use of Reserve Carryover as a Reserve Managem ment Tool: A Microeconometric Approach," Journal of Banking and Finance (March 1984), pp. 5-20.

Solomon, Anthony M. "Unresolved Issues in Monetary Policy," Federal Reserve Bank of New York Quarterly Review (Spring 1984), pp. +-6 .

Thornton, Daniel L. "Simple Analytics of the Money Supply Process and Monetary Control," this Review (October 1982), pp. 22-39.

"The FOMC in 1982: De-emphasizing M1," this Review (June/July 1983a), pp. 26-35.

"Lagged and Contemporaneous Reserve Accounting: An Alternative View," this Review (November 1983b), pp. 26-33.

Wallich, Henry C. "Recent Techniques of Monetary Policy," Federal Reserve Bank of Kansas City Economic Review (May 1984), pp. 21-30. 